\title{
Analisis Ekonomi Energi Perencanaan Pembangunan PLTS (Studi Kasus Gedung Kuliah Politeknik Negeri Ketapang)
}

\author{
Yudi Chandra

\begin{abstract}
Program Magister Teknik Elektro Fakultas Teknik Universitas Tanjungpura.
Teknik Elektro, Politeknik Negeri Ketapang

e-mail : chandra.yudi.2386@gmail.com
\end{abstract}

\begin{abstract}
Untuk memenuhi kebutuhan energi listrik di gedung kuliah Politeknik Negeri Ketapang (POLINKA) karena sering terjadinya pemadaman listrik bergilir, maka diperlukan suplai energi cadangan melalui pengembangan energi alternatif yang salah satunya adalah pengembangan PLTS. Sejalan dengan peraturan menteri ESDM tentang pembelian energi listrik dari Pembangkit Listrik Tenaga Surya (PLTS) oleh PT. Perusahaan Listrik Negar (Persero). PLTS merupakan salah satu energi alternatif yang cocok untuk menunjang kebutuhan energi listrik di POLINKA dengan pertimbangan kuat dan lama penyinaran matahari yang baik. Sebelum merealisasikan sistem PLTS di POLINKA, perlu suatu analisis untuk menentukan ekonomi energi yang diberikan oleh sistem PLTS tersebut. Preoses yang dilakukan untuk menganalisis ekonomi energi yang diberikan sistem PLTS ialah dari pengumpulan data lapangan selanjutnya perhitungan komponen PLTS dan kemudian menghitung kelayakan investasi. Dari perhitungan yang telah dilakukan, didapat beban rencana berdasarkan jumlah lampu, laptop, LCD projector tiap ruang kelas dengan menggunakan AC dan tanpa menggunakan AC pada gedung kuliah POLINKA yaitu: 56.763 watt (dengan AC) dan 18.963 watt (tanpa AC). Biaya investasi yang diperlukan berurutan untuk beban dengan AC dan tanpa AC sebesar Rp. 24.911.080.000 dan Rp. 8.310.360.000, dengan biaya energi/harga energi sebesar $R p$. 2.630,15/kWh dan Rp. 2.632,26/kWh. Hasil analisis kelayakan investasi dilakukan dengan NPV, PI, DPP, ROR menunjukan bahwa investasi PLTS layak untuk direalisasikan.
\end{abstract}

Keywords-Ekonomi energi, PLTS, POLINKA

\section{Pendahuluan}

Solusi untuk meningkatkan proses pembelajaran di daerah yang energi listriknya kurang khususnya di POLINKA diperlukan energi alternatif. PLTS merupakan salah satu energi alternatif yang cocok untuk menunjang kebutuhan energi listrik di POLINKA. Karena dilihat dari lokasi/tempat, POLINKA letaknya cukup jauh dari pesisir pantai dan pegunungan. Dan sejalan dengan Peraturan Menteri ESDM Nomor 19 Tahun 2016 tentang pembelian tenaga listrik dari PLTS oleh PT. PLN (persero). Sebelum merealisasikan sistem PLTS pada POLINKA, perlu suatu analisis ekonomi energi pada sistem PLTS tersebut.

\section{Teori Dasar}

\subsection{Sistem PLTS yang Digunakan dalam Penelitian}

Sistem PLTS yang digunakan dalam penelitian ini adalah sistem yang terhubung jaringan listrik dengan cadangan batere (grid connected photovoltaic battery backup). Seperti penjelasan sebelumnya dengan menggunakan sistem PLTS ini, saat terjadi pemadaman listrik dari PLN, gedung kuliah masih mendapatkan enegi listrik yang dihasilkan dari modul PV atau dari batere jika modul PV tidak menghasilkan energi karena cuaca mendung atau malam hari. Dengan demikian energi listrik yang diperlukan oleh gedung kuliah di POLINKA tetap terpenuhi.

\subsection{Temperatur ${ }^{[1]}$}

Sebuah modul PV akan bekerja maksimum apabila suhu lingkungan sekitarnya berada pada angka $25^{\circ} \mathrm{C}$. kenaikan temperatur yang lebih tinggi dari temperatur normal akan mengurangi kinerja modul PV dalam menghasilkan tegangan. Setiap kenaikan $1^{\circ} \mathrm{C}$ akan mengurangi sekitar $0,5 \%$ dari total daya yang dihasilkan. Untuk menghitung besar daya modul PV yang berkurang pada saat temperatur naik $1{ }^{\circ} \mathrm{C}$ maka bisa menggunakan rumus berikut:

$\mathrm{P}_{\text {saat naik }} \mathrm{t}^{\circ} \mathrm{C}=0,5 \% /{ }^{\circ} \mathrm{C} \times \mathrm{P}_{\mathrm{Mpp}} \mathrm{x}$ kenaikan
temperatur $\left({ }^{\circ} \mathrm{C}\right)$

Keterangan:

$\mathrm{P}_{\text {saat naik } t}{ }^{\circ} \mathrm{C}$ : Daya keluaran modul PV pada saat temperatur naik $t{ }^{\circ} \mathrm{C}$ dari angka $25^{\circ} \mathrm{C}, \mathrm{P}_{\mathrm{Mpp}}$ : Daya keluaran maksimum modul PV

Daya keluaran maksimum modul PV pada saat temperaturnya naik jadi t ${ }^{\circ} \mathrm{C}$ dari angka $25^{\circ} \mathrm{C}$ maka dapat dihitung dengan rumus berikut:

$\mathrm{P}_{\text {Mpp saat naik }} \mathrm{t}^{\circ} \mathrm{C}=\mathrm{P}_{\mathrm{Mpp}}$ - Psaat naik $\mathrm{t}^{\circ} \mathrm{C}$

Keterangan:

$\mathrm{P}_{\text {Mpp saat naik }} \mathrm{t}^{\circ} \mathrm{C}$ : Daya keluaran maksimal modul PV pada saat temperatur di sekitar modul PV naik t ${ }^{\circ} \mathrm{C}$ dari angka $25^{\circ} \mathrm{C}$

\subsection{Perhitungan Lama Penyinaran Matahari}

Dalam mendapatkan data lama penyinaran matahari diperoleh dari stasiun BMKG wilayah Kabupaten Ketapang. Data yang didapat berupa tabel lama penyinaran matahari harian dan di rata-ratakan dalam sebulan dengan satuan persen (\%). Data yang didapat 
dilakukan perhitungan kembali menjadi rata-rata dalam setahun dan kemudian dikonversi menjadi jam dengan perhitungan $100 \%$ sama dengan 8 jam. Dari uraian tersebut, perhitungan rata-rata lama penyinaran matahari dapat dirumuskan ke dalam matematika ${ }^{[2]}$ sebagai berikut:

$$
I M=\frac{\sum_{i=1}^{n} B_{i}}{n} \times 8
$$

Keterangan :

IM : Nilai rata-rata lamanya penyinaran matahari (jam)

$B$ : rata-rata lamanya penyinaran matahari bulanan $(\%)$

8 : Konversi data BMKG dari persen (\%) menjadi jam

\subsection{Perhitungan Kapasitas Sistem PLTS ${ }^{[3]}$}

Kapasitas energi listrik yang dihasilkan sistem PLTS adalah gabungan dari kapasitas setiap komponen dalam sistem PLTS. Kebutuhan beban listrik adalah dasar dari penentuan kapasitas sistem PLTS dan dapat dihitung dengan persamaan di bawah ini:

$$
E_{T}=P_{T} \times h
$$

Keterangan :

$E_{T}$ : Total pemakaian per hari $(\mathrm{Wh}), P_{T}$ : Beban listrik (watt), $h:$ Lama pemakaian (jam)

Dalam setiap instalasi listrik terjadi kerugingankerugian tegangan. Kerugian diperbolehkan sebesar 5\% dari total beban, maka penentuan kapasitas sistem PLTS ditambahkan dengan kerugian tegangan dari instalasi. Sehingga perhitungan total energi $\left(\mathrm{E}_{\mathrm{T}}\right)$ menjadi:

$$
E_{T}=1,05 \times P_{T} \times h
$$

\subsubsection{Kapasitas Inverter ${ }^{[3]}$}

Menentukan maksimum inverter bertujuan untuk mengetahui daya keluaran inverter yang dibutuhkan agar tidak kurang dari beban listrik yang dibutuhkan, dipengaruhi oleh efisiensi dari inverter yang akan dipilih. Persamaan yang digunakan yaitu:

$$
\text { DMI total }=\frac{1,05 \times P_{T}}{\eta_{i}}
$$

Keterangan:

DMI total : Total daya maksimum keluaran inverter (watt), $\eta_{i}$ : Efisiensi inverter

Selanjutnya ialah menentukan jumlah inverter. Jumlah inverter yang dibutuhkan dari total daya maksimum inverter ditentukan dengan persamaan:

$$
J_{i}=\frac{\text { DMI total }}{D M I}
$$

Keterangan:

$J i$ : Jumlah inverter, DMI : Daya maksimum keluaran inverter yang dipilih (watt)

\subsubsection{Kapasitas Batere ${ }^{[3]}$}

Untuk memenuhi kapasitas batere yang dibutuhkan adalah dengan menghitung berapa arus batere yang dibutuhkan untuk menampung daya yang dihasilkan modul PV sehingga mampu mensuplai sama dengan total pemakaian energi per hari dengan persamaan:

$$
I_{b} \text { total }=\frac{E_{T} \times t}{V_{i} \times \eta_{b}}
$$

Keterangan :

$I_{b}$ total : Total arus batere (Ah), $t:$ Waktu cadangan, $V_{i}$ : Tegangan input inverter ( volt ), $\eta_{b}$ : Efisiensi batere (\%)

2.4.3 Minimum Arus Solar Charge Controller (SCC) ${ }^{[3]}$

$$
I_{s} \min =\frac{I_{b} \text { total }}{I M x \eta_{s}}
$$

Keterangan:

$I_{s}$ min : Arus SCC yang dibutuhkan (A), $\eta_{\mathrm{s}}$ : Efisiensi $\mathrm{SCC}(\%)$

Selanjutnya ialah menentukan jumlah SCC yang dibutuhkan untuk dapat mengisi batere per hari ditentukan dengan persamaan:

$$
J_{s}=\frac{I_{s} \min }{I_{s}}
$$

Keterangan:

$J_{s}$ : Jumlah SCC, $I_{s}$ : Kapasitas arus SCC yang di gunakan (A)

\subsubsection{Kapasitas Daya Modul PV ${ }^{[4]}$}

Kapasitas daya modul PV adalah kapasitas daya yang dibutukan berdasarkan arus maksimum dari SCC dan tegangan yang digunakan yaitu tegangan input inverter dihitung dengan persamaan dibawah ini:

$$
P_{M}=I_{s} \min x V_{i}
$$

Keterangan:

$P_{M}$ : Kapasitas daya modul PV ( Wp )

Dari kapasitas daya modul PV, maka untuk jumlah modul PV yang akan digunakan berdasarkan jenis modul PV yang dipilih dapat dihitung dengan persamaan berikut:

$$
J_{m}=\frac{P_{M}}{\eta_{m} \times P_{M P P} x\left(1-\left(0,5 \% \times T_{h}\right)\right)}
$$

Keterangan:

$J_{m}$ : Jumlah modul PV, $\eta_{m}$ : Efisiensi modul PV (\%), $T_{h}$ : Kenaikan temperatur dari temperatur normal modul PV

\subsection{Analisis Ekonomi Energi}

Untuk bisa melakukan analisis ekonomi energi, yang dibutuhkan seperti sebagai berikut:

\subsubsection{Biaya Tetap (Fixed Cost $)^{[5]}$}

Biaya tetap (fixed cost) adalah estimasi biaya investasi awal dalam perencanaan PLTS ini adalah biaya pembuatan PLTS.

\subsubsection{Biaya Tidak Tetap (Variable Cost $)^{[4]}$}

Biaya tidak tetap (variable cost) adalah biaya pemeliharaan dan operasional per tahun untuk PLTS yang umumnya digunakan sebesar 1-2 \% dari total biaya investasi awal ${ }^{[12]}$. Adapun persamaannya adalah:

$$
M=1-2 \% x \text { Total investasi awal }
$$




\subsubsection{Lamanya Sistem Bisa Beroperasi (Umur Ekonomis) ${ }^{[5]}$}

Lamanya sistem bisa beroperasi (umur ekonomis) adalah lama umur dari sistem PLTS yang akan dikerjakan bisa beroperasi.

\subsubsection{Ongkos dan Tarif / Nilai Jual Produksi Energi Listrik $^{[4]}$}

Ongkos dan tarif/nilai jual produksi energi listrik adalah biaya energi per $\mathrm{kWh}$ dari energi yang dihasilkan. Untuk mendapatkan biaya tersebut, harus mengetahui biaya siklus hidup (LCC) dari sistem PLTS yang akan direncanakan dan produksi enegi per tahun pada sistem PLTS. Biaya siklus hidup (LCC) pada PLTS yang akan direncanakan ini, ditentukan oleh nilai sekarang dari biaya total sistem PLTS yang terdisi dari investasi awal (C) dan biaya jangka panjang untuk pemeliharaan dan operasional $\left(\mathrm{M}_{\mathrm{pw}}\right)$. Dapat dihitung dengan rumus:

$$
L C C=\mathrm{C}+\mathrm{M}_{\mathrm{pw}}
$$

Setelah mengetahui biaya siklus hidup, meghitung produksi energi per tahun dari sistem PLTS yang akan direncanakan. Untuk mengetahui $\mathrm{kWh}$ produksi per tahun dapat dihitung dengan persamaan:

$$
A k W h=\frac{P_{M \text { total }} \times 365}{1000}
$$

Keterangan:

A $k W h$ : kWh produksi per tahun (kWh), 365 : Jumlah hari dalam setahun, 1000 : Konversi dari W ke kW

Perhitungan biaya energi (cost of energy) suatu PLTS ditentukan berdasarkan biaya siklus hidup (LCC) yang dirubah menjadi serangkaian biaya tahunan atau deret seragam yang dipengaruhi oleh suku bunga (MARR yang digunakan) dibagi dengan $\mathrm{kWh}$ produksi per tahun. Dapat dituliskan dengan persamaan:

$$
C O E=\frac{L C C x(A / P, i \% . N)}{A k W h}
$$

Keterangan:

COE : Biaya energi per kWh $(\mathrm{Rp})$

\subsubsection{Analisis Kelayakan Investasi}

Kelayakan investasi dilakukan dengan cara menganalisa ekonomi dari investasi suatu pembangkit listrik tenaga surya (PLTS) yang akan dirancang di gedung kuliah POLINKA. Tahapan dalam melakukan analisis kelayakan investasi pada perencanaan PLTS ini yaitu:

\section{1) Net Present Value (NPV) ${ }^{[4]}$}

Net present value (NPV) adalah selisih antara pengeluaran dan pemasukan yang telah didiskon dengan menggunakan cost of capital sebagai diskon faktor. Dengan kata lain merupakan arus kas yang diperkirakan pada masa yang akan datang. Persamaan NPV diperhitungkan dengan rumus dibawah ini:

$$
N P V=\sum_{t=1}^{n} \frac{N C F_{t}}{(1+r)^{t}}-I I
$$

Keterangan:

$I I$ : Investasi awal, $r$ : Tingkat diskonto, $N C F_{t}$ : Alur kas bersih setiap tahun

Keterangan pengambilan keputusannya ${ }^{[1]}$ adalah sebagai berikut:

- Jika nilai NPV adalah positif maka proyek layak dilaksanakan karena hal itu mengindikasikan bahwa perhitungan investasi proyek mampu memberi keuntungan sampai periode yang diperhitungkan.

- Jika nilai NPV adalah negatif maka proyek tidak layak dilaksanakan karena hal itu mengindikasikan bahwa perhitungan investasi proyek belum mampu memberi keuntungan sampai periode yang diperhitungkan.

- Jika nilai NPV adalah 0 maka itu berarti dalam sepanjang periode perhitungan investasi yang dilakukan maka proyek tersebut telah memberikan hasil yang sebanding dengan nilai investasi yang dikeluarkan.

\section{2) Profitability Index (PI) ${ }^{[4]}$}

Profitability index ( PI ) adalah perbandingan antara nilai arus kas bersih yang akan datang dengan nilai investasi yang sekarang. Kelayakan investasi menurut standar analisa ini adalah :

- Jika PI > 1 ; maka investasi tersebut dapat dijalankan (layak)

- Jika PI < 1 ; investasi tersebut tidak layak dijalankan (tidak layak)

Persamaan profitability index (PI) diperhitungkan dengan rumus dibawah ini:

$$
P I=\frac{\sum_{t=1}^{n} N C F_{t}(1+r)^{-t}}{I I}
$$

\section{3) Discounted Payback Period (DPP) $)^{[4]}$}

Teknik discounted payback period (DPP) adalah periode pengembalian modal yang dihitung dengan menggunakan discount factor. DPP dapat diperoleh dengan menghitung berapa tahun nilai sekarang arus kas bersih komulatif akan sama atau lebih kecil dari umur proyek yang di rencanakan.

kriteria pengambilan keputusan suatu perencanaan layak diimplementasikan atau tidak layak dalam metode ini adalah:

- Perencanaan akan dinilai layak apabila DPP memiliki periode waktu lebih pendek dari umur perencanaan.

- Perencanaan belum dinilai layak apabila DPP memiliki periode waktu lebih panjang dari umur perencanaan.

\section{4) Perhitungan dan Analisis Rate Of Return (ROR) ${ }^{[5]}$}

Rate of Return (ROR) adalah tingkat bunga yang menyebabkan terjadinya keseimbangan antara semua pengeluaran dan pemasukan pada suatu periode tertentu. Dengan kata lain ROR adalah suatu tingkat penghasilan yang mengakibatkan nilai NPV dari suatu investasi sama dengan nol. Dalam analisis kelayakan investasi perencanaan PLTS ini, analisis ROR yang digunakan yaitu IRR dimana semua aliran kas dirubah menjadi 
nilai sekarang. Persamaan yang digunakan untuk menentukan IRR adalah:

$$
\mathrm{NPV}=\mathrm{PV}_{\mathrm{R}}-\mathrm{PV}_{\mathrm{E}}
$$

Keterangan:

NPV : Net Present Value bernilai, $\mathrm{PV}_{\mathrm{R}}$ : Present Value dari semua pemasukan, $\mathrm{PV}_{\mathrm{E}}$ : Present Value dari semua pengeluaran

Suatu investasi dikatakan layak untuk dilaksanakan apabila ROR/IRR yang dihasilkan lebih besar atau sama dengan MARR.

\section{Pengolahan Data dan Analisis}

\subsection{Pengumpulan Data}

Dalam penelitian ini, pengambilan data dilakukan pada ruang kelas gedung kuliah POLINKA untuk data beban listrik dan data lamanya penyinaran matahari di stasiun BMKG wilayah Kabupaten Ketapang. Adapun data beban listrik pada ruang kelas gedung kuliah POLINKA adalah:

Tabel 1. Data Beban Listrik dengan AC

\begin{tabular}{lccc}
\multicolumn{4}{c}{ Tabel 1. Data Beban Listrik dengan AC } \\
\hline Komponen & Banyak & $\begin{array}{c}\text { Daya satuan } \\
(\mathrm{W})\end{array}$ & $\begin{array}{c}\text { Jumlah } \\
(\mathrm{W})\end{array}$ \\
\hline \hline Lampu & 126 & 24 & 3.024 \\
\hline Laptop & 21 & 330 & 6.930 \\
\hline LCD Projector & 21 & 429 & 9.009 \\
\hline AC ( 2pk ) & 21 & 1800 & 37.800 \\
\hline & Total Beban & & $\mathbf{5 6 . 7 6 3}$ \\
\hline
\end{tabular}

Sumber : Gedung Kuliah POLINKA

Tabel 2. Data Beban Listrik tanpa AC

\begin{tabular}{lccc}
\hline Komponen & Banyak & $\begin{array}{c}\text { Daya satuan } \\
(\mathrm{W})\end{array}$ & $\begin{array}{c}\text { Jumlah } \\
(\mathrm{W})\end{array}$ \\
\hline \hline Lampu & 126 & 24 & 3.024 \\
\hline Laptop & 21 & 330 & 6.930 \\
\hline LCD Projector & 21 & 429 & 9.009 \\
\hline \multicolumn{4}{c}{ Total Beban } \\
\hline
\end{tabular}

Sumber : Gedung Kuliah POLINKA

Untuk data lamanya penyinaran matahari dari Stasiun BMKG wilayah Kabupaten Ketapang terlampir. Dari data yang didapat dilakukan perhitungan dengan menggunakan rumus persamaan (3) sebagai berikut:

$$
\begin{aligned}
& I M=\frac{\sum_{i=1}^{n} B_{i}}{n} \times 8 \\
& I M=\frac{845,0005 \%}{12} \times 8 \\
& I M=5,63 \mathrm{jam}
\end{aligned}
$$

Dari hasil perhitungan yang telah dilakukan, maka lama penyinaran matahari yang digunakan dalam perhitungan adalah 5,63 jam.

\subsection{Hasil Perhitungan Komponen PLTS}

Dari perhitungan komponen PLTS yang telah dilakukan, didapat jumlah komponen PLTS yang akan digunakan pada sistem PLTS yaitu pada tabel 3 dibawah ini:

Tabel 3. Hasil Perhitungan Komponen PLTS

\begin{tabular}{clcc}
\hline No & Komponen & Perhitungan 1 & Perhitungan 2 \\
\hline \hline 1 & Inverter & 15 & 5 \\
\hline 2 & Batere & 5040 & 1680 \\
\hline 3 & SCC & 210 & 70 \\
\hline 4 & Modul PV & 2520 & 840 \\
\hline
\end{tabular}

Keterangan:

Perhitungan 1: Beban rencana dengan AC

Perhitungan 2: Beban rencana tanpa AC

\subsection{Biaya Investasi PLTS}

Keseluruhan informasi untuk setiap komponen biaya investasi awal sistem PLTS untuk komponen PLTS didapat dari mencari informasi dari website yang menjual komponen-komponen sistem PLTS, untuk biaya pengiriman, kabel, rak dan lemari didapat dari survei ke pasar yang ada di ketapang dan untuk biaya dudukan modul PV dan biaya instalasi dan pemasangan didapat dari konsultasi dengan ahli PLTS. Adapun biaya investasi yang diperlukan diuraikan pada tabel di bawah.

Dalam penelitian ini, skenario pendanaan biaya investasi berdasarkan pinjaman dari BANK. Karena itu, tingkat bunga yang digunakan dalam perhitungan

\begin{tabular}{|c|c|c|c|c|c|}
\hline No & Komponen & Jumlah & Satuan & Harga & Total Harga \\
\hline 1 & Inverter & 15 & Buah & $\begin{array}{ll}\text { Rp. } & 24.906 .000\end{array}$ & $\begin{array}{ll}\text { Rp. } & 373.590 .000 \\
\end{array}$ \\
\hline 2 & Batere & 5.040 & Buah & $\begin{array}{ll}\text { Rp. } & 1.900 .000\end{array}$ & Rp. 9.576 .000 .000 \\
\hline 3 & SCC & 210 & Buah & 3.088 .000 & $\begin{array}{ll}\text { Rp. } & 648.480 .000 \\
\end{array}$ \\
\hline 4 & Modul PV & 2.520 & Buah & 4.800 .000 & Rp. 12.096.000.000 \\
\hline 5 & Connector & 2.520 & Buah & 45.000 & $\begin{array}{ll}\text { Rp. } & 113.400 .000 \\
\end{array}$ \\
\hline 6 & Connector Y & 1.050 & Buah & 155.000 & $\begin{array}{ll}\text { Rp. } & 162.750 .000 \\
\end{array}$ \\
\hline 7 & Biaya Pengiriman Komponen & 146.196 & $\mathrm{Kg}$ & 10.000 & $\begin{array}{ll}\text { Rp. } & 1.461 .960 .000 \\
\end{array}$ \\
\hline 8 & Kabel $2 \times 2,5 \mathrm{~mm}$ & 2.940 & Meter & 10.000 & $\begin{array}{ll}\text { Rp. } & 29.400 .000 \\
\end{array}$ \\
\hline 9 & Rak Batere & 30 & Buah & 1.500 .000 & 45.000 .000 \\
\hline 10 & lemari Box & 15 & Buah & 3.500 .000 & 52.500 .000 \\
\hline 11 & Dudukan Modul PV & 2.520 & Buah & $\begin{array}{ll}\text { Rp. } & 100.000 \\
\end{array}$ & 252.000 .000 \\
\hline 12 & Biaya Instalasi dan Pemasangan & 1 & & Rp. 100.000 .000 & $\begin{array}{ll}\text { Rp. } & 100.000 .000 \\
\end{array}$ \\
\hline
\end{tabular}
penelitian yaitu suku bunga BANK pada saat penelitian dilakukan yaitu sebesar $9 \%$.

Tabel 4. Biaya Investasi Berdasarkan Beban Rencana dengan AC 
Tabel 5. Biaya Investasi Berdasarkan Beban Rencana tanpa AC

\begin{tabular}{|c|c|c|c|c|c|}
\hline No & Komponen & Jumlah & Satuan & Harga & Total Harga \\
\hline 1 & Inverter & 5 & Buah & Rp. 24.906.000 & $\begin{array}{ll}\text { Rp. } & 124.530 .000 \\
\end{array}$ \\
\hline 2 & Batere & 1.680 & Buah & $\begin{array}{ll}\text { Rp. } & 1.900 .000 \\
\end{array}$ & Rp. 3.192.000.000 \\
\hline 3 & SCC & 70 & Buah & $\begin{array}{ll}\text { Rp. } & 3.088 .000 \\
\end{array}$ & $\begin{array}{ll}\text { Rp. } & 216.160 .000 \\
\end{array}$ \\
\hline 4 & Modul PV & 840 & Buah & $\begin{array}{ll}\text { Rp. } & 4.800 .000 \\
\end{array}$ & Rp. 4.032.000.000 \\
\hline 5 & Connector & 840 & Buah & Rp. $\quad 45.000$ & $\begin{array}{ll}\text { Rp. } & 37.800 .000\end{array}$ \\
\hline 6 & Connector Y & 350 & Buah & 155.000 & 54.250 .000 \\
\hline 7 & Biaya Pengiriman Komponen & 48.732 & $\mathrm{Kg}$ & 10.000 & $\begin{array}{ll}\text { Rp. } & 487.320 .000 \\
\end{array}$ \\
\hline 8 & Kabel $2 \times 2,5 \mathrm{~mm}$ & 980 & Meter & 10.000 & 9.800 .000 \\
\hline 9 & Rak Batere & 10 & Buah & 1.500 .000 & 15.000 .000 \\
\hline 10 & lemari Box & 5 & Buah & $\begin{array}{ll}\text { Rp. } & 3.500 .000 \\
\end{array}$ & 17.500 .000 \\
\hline 11 & Dudukan Modul PV & 840 & Buah & $\begin{array}{ll}\text { Rp. } & 100.000 \\
\end{array}$ & 84.000 .000 \\
\hline 12 & Biaya Instalasi dan Pemasangan & 1 & & Rp. 40.000 .000 & $\begin{array}{ll}\text { Rp. } & 40.000 .000 \\
\end{array}$ \\
\hline \multicolumn{5}{|c|}{ Total Biaya Investasi } & Rp. 8.310.360.000 \\
\hline
\end{tabular}

\subsection{Ongkos dan Tarif / Nilai Jual Produksi Energi Listrik}

Ongkos dan tarif/nilai jual produksi energi listrik adalah biaya energi per $\mathrm{kWh}$ dari energi yang dihasilkan. Untuk mendapatkan biaya tersebut, harus mengetahui biaya siklus hidup (LCC) per tahun pada sistem PLTS. Biaya siklus hidup (LCC) pada PLTS, ditentukan oleh nilai sekarang dari biaya total sistem PLTS yang terdisi dari investasi awal (C) dan biaya jangka panjang untuk pemeliharaan dan operasional $\left(\mathrm{M}_{\mathrm{pw}}\right)$. Hasil yang didapat dari perhitungan yang telah dilakukan diuraikan dalam tabel dibawah.

Tabel 6. Hasil Perhitungan Ongkos dan Tarif / Nilai Jual Produksi Energi Listrik

\begin{tabular}{|c|c|c|c|c|}
\hline \multirow{2}{*}{ No } & \multirow{2}{*}{ Perhitungan } & \multirow{2}{*}{ Simbol } & \multicolumn{2}{|c|}{ Hasil Perhitungan } \\
\hline & & & dengan $\mathrm{AC}$ & tanpa AC \\
\hline 1 & Biaya Pemeliharaan dan Operasional & $\mathrm{M}_{\mathrm{PW}}$ & Rp. 6.227 .770 .000 & Rp. 2.077 .590 .000 \\
\hline 2 & Biaya Siklus Hidup & LCC & Rp. 31.138 .850 .000 & Rp. 10.387 .950 .000 \\
\hline 3 & kWh Produksi & $\mathrm{A} \mathrm{kWh}$ & $1.211 .762,9160 \mathrm{kWh}$ & $403.920,9720 \mathrm{kWh}$ \\
\hline 4 & Biaya Energi & $\mathrm{COE}$ & Rp. 2.616,13 / kWh & Rp. $2.618,23 / \mathrm{kWh}$ \\
\hline
\end{tabular}

\subsection{Aliran Kas (Cash Flow)}

Tabel 7. Aliran Kas Berdasarkan Beban Rencana dengan AC

\begin{tabular}{|c|c|c|c|c|c|c|c|c|c|c|c|c|c|}
\hline \multirow{2}{*}{$\begin{array}{c}\text { Tahun } \\
0\end{array}$} & \multirow{2}{*}{\multicolumn{2}{|c|}{$\begin{array}{l}\text { Biaya } \\
(24.911 .080 .000)\end{array}$}} & \multicolumn{2}{|c|}{ Alur Kas Masuk } & \multicolumn{2}{|c|}{ Alur Kas Keluar } & \multicolumn{2}{|r|}{ NCF } & \multirow{2}{*}{$\begin{array}{r}\text { DF } \\
1\end{array}$} & \multicolumn{2}{|r|}{ PVNCF } & \multicolumn{2}{|c|}{ Kumulatif PVNCF } \\
\hline & & & & & & & & & & & & $\overline{\mathrm{Rp}}$ & 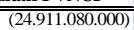 \\
\hline & & & $\mathrm{Rp}$ & 3.170 .129 .564 & Rp & $\begin{array}{l}(249.110 .800) \\
\end{array}$ & $\mathrm{Rp}$ & 2.921 .018 .764 & 0,9174 & $\mathrm{Rp}$ & 2.679 .833 .728 & $\mathrm{Rp}$ & $(22.231 .246 .272)$ \\
\hline 2 & & & $\mathrm{Rp}$ & 3.170 .129 .564 & $\mathrm{Rp}$ & $(249.110 .800)$ & $\mathrm{Rp}$ & 2.921 .018 .764 & 0,8417 & $\mathrm{Rp}$ & 2.458 .563 .054 & $\mathrm{Rp}$ & $(19.772 .683 .218)$ \\
\hline$\frac{2}{3}$ & & & $\mathrm{Rp}$ & 3.170 .129 .564 & $\mathrm{Rp}$ & $(249.110 .800)$ & $\mathrm{Rp}$ & 2.921 .018 .764 & $0,0,0722$ & $\mathrm{Rp}$ & 2.255 .562 .434 & $\mathrm{Rp}$ & $(17.517 .120 .784)$ \\
\hline 4 & & & $\mathrm{Rp}$ & 3.170 .129 .564 & $\mathrm{Rp}$ & $(249.110 .800)$ & $\mathrm{Rp}$ & 2.921 .018 .764 & 0,7084 & $\mathrm{Rp}$ & 2.069 .323 .334 & $\mathrm{Rp}$ & (15.447.797.449) \\
\hline 5 & & & $\mathrm{Rp}$ & 3.170 .129 .564 & $\mathrm{Rp}$ & $(249.110 .800)$ & $\mathrm{Rp}$ & 2.921 .018 .764 & $\begin{array}{l}0,10049 \\
0,6499\end{array}$ & $\frac{\mathrm{Pp}}{\mathrm{Rp}}$ & 1.898 .461 .775 & $\mathrm{Rp}$ & $(13.549 .335 .674)$ \\
\hline$\frac{3}{6}$ & & & $\mathrm{Rp}$ & 3.170 .129 .564 & $\mathrm{Rp}$ & $(249.110 .800)$ & $\mathrm{Rp}$ & 2.921 .018 .764 & 0,5963 & $\mathrm{Rp}$ & 1.741 .708 .050 & $\mathrm{Rp}$ & $(11.807 .627 .624)$ \\
\hline 7 & & & $\mathrm{Rp}$ & 3.170 .129 .564 & $\mathrm{Rp}$ & $(249.110 .800)$ & $\mathrm{Rp}$ & 2.921 .018 .764 & 0,5470 & $\mathrm{Rp}$ & 1.597 .897 .294 & $\mathrm{Rp}$ & $(10.209 .730 .331)$ \\
\hline 8 & & & $\mathrm{Rp}$ & 3.170 .129 .564 & $\mathrm{Rp}$ & $(249.110 .800)$ & $\mathrm{Rp}$ & 2.921 .018 .764 & 0,5019 & $\mathrm{Rp}$ & 1.465 .960 .820 & $\mathrm{Rp}$ & $(8.743 .769 .511)$ \\
\hline 9 & & & $\mathrm{Rp}$ & 3.170 .129 .564 & $\mathrm{Rp}$ & $(249.110 .800)$ & $\mathrm{Rp}$ & 2.921 .018 .764 & 0,4604 & $\mathrm{Rp}$ & $\begin{array}{l}1.4034 .9018 .183 \\
\end{array}$ & $\mathrm{Rp}$ & $\begin{array}{l}(0.7398 .851 .327) \\
(7.390)\end{array}$ \\
\hline 10 & & & $\mathrm{Rp}$ & 3.170 .129 .564 & $\mathrm{Rp}$ & $(249.110 .800)$ & $\mathrm{Rp}$ & 2.921 .018 .764 & $\frac{0,400+4}{0,4224}$ & $\mathrm{Rp}$ & 1.233 .869 .893 & $\mathrm{Rp}$ & (6.164.981.434) \\
\hline 11 & & & $\mathrm{Rp}$ & 3.170 .129 .564 & $\mathrm{Rp}$ & $(249.110 .800)$ & $\mathrm{Rp}$ & 2.921 .018 .764 & 0,3875 & $\mathrm{Rp}$ & 1.131 .990 .728 & $\mathrm{Rp}$ & $(5.032 .990 .707)$ \\
\hline$\frac{11}{12}$ & & & $\mathrm{Rp}$ & 3.170 .129 .564 & $\mathrm{Rp}$ & $(249.110 .800)$ & $\mathrm{Rp}$ & 2.921 .018 .764 & $\frac{0,301 / 5}{0,3555}$ & $\mathrm{Rp}$ & 1.038 .523 .603 & $\mathrm{Rp}$ & (3.994.467.103) \\
\hline 13 & & & $\mathrm{Rp}$ & 3.170 .129 .564 & $\mathrm{Rp}$ & $(249.110 .800)$ & $\mathrm{Rp}$ & 2.921 .018 .764 & $\begin{array}{l}0,3535 \\
0,3262\end{array}$ & $\mathrm{Rp}$ & 952.773 .948 & $\mathrm{Rp}$ & $(3.041 .693 .155)$ \\
\hline 14 & & & $\mathrm{Rp}$ & 3.170 .129 .564 & $\mathrm{Rp}$ & $(249.110 .800)$ & $\mathrm{Rp}$ & 2.921 .018 .764 & $\begin{array}{l}0,02922 \\
0,2992\end{array}$ & $\mathrm{Rp}$ & 874.104 .539 & $\mathrm{Rp}$ & $(2.167 .588 .616)$ \\
\hline 15 & & & $\mathrm{Rp}$ & 3.170 .129 .564 & $\mathrm{Rp}$ & $(249.110 .800)$ & $\mathrm{Rp}$ & 2.921 .018 .764 & 0,2745 & $\mathrm{Rp}$ & 801.930 .770 & $\mathrm{Rp}$ & $(1.365 .657 .846)$ \\
\hline 16 & & & $\mathrm{Rp}$ & 3.170 .129 .564 & $\mathrm{Rp}$ & $(249.110 .800)$ & $\mathrm{Rp}$ & 2.921 .018 .764 & $\begin{array}{l}, 24.5 \\
0,2519\end{array}$ & $\mathrm{Rp}$ & 735.716.303 & $\mathrm{Rp}$ & (1.1050.051.040) \\
\hline 17 & & & $\mathrm{Rp}$ & 3.170 .129 .564 & $\mathrm{Rp}$ & $(249.110 .800)$ & $\mathrm{Rp}$ & 2.921 .018 .764 & 0,2311 & $\mathrm{Rp}$ & 674.969 .085 & $\mathrm{Rp}$ & 45.027 .542 \\
\hline 18 & & & $\mathrm{Rp}$ & 3.170 .129 .564 & $\mathrm{Rp}$ & $(249.110 .800)$ & $\mathrm{Rp}$ & 2.921 .018 .764 & 0,2120 & $\mathrm{Rp}$ & 619.237 .693 & $\mathrm{Rp}$ & 664.265 .235 \\
\hline$\frac{18}{19}$ & & & $\frac{\mathrm{Np}}{\mathrm{Rp}}$ & $\frac{3.170 .129 .564}{3.170 .129 .564}$ & $\frac{\mathrm{Np}}{\mathrm{Rp}}$ & $\frac{(29.110 .0000)}{(249.110 .800)}$ & $\mathrm{Rp}$ & 2.921 .018 .764 & $\frac{0,2120}{0,1945}$ & $\frac{\mathrm{Np}}{\mathrm{Rp}}$ & 568.107 .975 & $\mathrm{Rp}$ & 1.232 .373 .210 \\
\hline 20 & & & $\mathrm{Rp}$ & 3.170 .129 .564 & $\mathrm{Rp}$ & $(249.110 .800)$ & $\mathrm{Rp}$ & 2.921 .018 .764 & 0,1784 & $\mathrm{Rp}$ & 521.199 .977 & $\mathrm{Rp}$ & 1.753 .573 .187 \\
\hline 21 & & & $\mathrm{Rp}$ & 3.170 .129 .564 & $\mathrm{Rp}$ & $(249.110 .800)$ & $\mathrm{Rp}$ & 2.921 .018 .764 & $\begin{array}{l}0,1637 \\
0,1637\end{array}$ & $\mathrm{Rp}$ & 478.165 .117 & $\mathrm{Rp}$ & 2.231 .738 .304 \\
\hline 22 & & & $\mathrm{Rp}$ & 3.170 .129 .564 & $\mathrm{Rp}$ & $(249.110 .800)$ & $\mathrm{Rp}$ & 2.921 .018 .764 & 0,1502 & $\mathrm{Rp}$ & 438.683 .593 & $\mathrm{Rp}$ & 2.670 .421 .897 \\
\hline$\frac{22}{23}$ & & & $\mathrm{Rp}$ & 3.170 .129 .564 & $\mathrm{Rp}$ & $(249.110 .800)$ & $\mathrm{Rp}$ & 2.921 .018 .764 & $\begin{array}{l}0,1502 \\
0,1378\end{array}$ & $\mathrm{Rp}$ & $\begin{array}{l}402.462 .012 \\
402.012\end{array}$ & $\mathrm{Rp}$ & 3.072 .883 .909 \\
\hline 24 & & & $\mathrm{Rp}$ & 3.170 .129 .564 & $\mathrm{Rp}$ & $(249.110 .800)$ & $\mathrm{Rp}$ & 2.921 .018 .764 & $\begin{array}{l}0,1360 \\
0,1264\end{array}$ & $\mathrm{Rp}$ & 369.231 .204 & $\mathrm{Rp}$ & 3.442 .115 .113 \\
\hline 25 & & & $\mathrm{Rp}$ & 3.170 .129 .564 & $\mathrm{Rp}$ & $(249.110 .800)$ & $\mathrm{Rp}$ & 2.921 .018 .764 & 0,1160 & $\mathrm{Rp}$ & 338.744 .224 & $\mathrm{Rp}$ & 3.780 .859 .337 \\
\hline & & & & & & & & & & $\mathrm{Rp}$ & 28.691 .939337 & & \\
\hline
\end{tabular}


Tabel 8. Aliran Kas Berdasarkan Beban Rencana tanpa AC

\begin{tabular}{|c|c|c|c|c|c|c|c|c|c|c|c|c|c|}
\hline \multirow{2}{*}{$\begin{array}{c}\text { Tahun } \\
0\end{array}$} & \multirow[b]{2}{*}{$\overline{\overline{R p}}$} & \multirow{2}{*}{$\begin{array}{l}\text { Biaya } \\
(8.310 .360 .000)\end{array}$} & \multicolumn{2}{|c|}{ Alur Kas Masuk } & \multicolumn{2}{|c|}{ Alur Kas Keluar } & \multicolumn{2}{|r|}{ NCF } & \multirow{2}{*}{$\begin{array}{c}\text { DF } \\
1\end{array}$} & \multicolumn{2}{|r|}{ PVNCF } & \multicolumn{2}{|c|}{ Kumulatif PVNCF } \\
\hline & & & 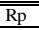 & & 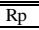 & & $\overline{\mathrm{Rp}}$ & & & & & $\overline{\mathrm{Rp}}$ & $\begin{array}{l}(8.310 .360 .000) \\
\end{array}$ \\
\hline 1 & & & $\mathrm{Rp}$ & 1.057 .558 .240 & $\mathrm{Rp}$ & (83.103.600) & $\mathrm{Rp}$ & 974.454 .640 & 0,91743 & $\mathrm{Rp}$ & 893.995 .083 & $\mathrm{Rp}$ & $(7.416 .364 .917)$ \\
\hline 2 & & & $\mathrm{Rp}$ & 1.057 .558 .240 & $\mathrm{Rp}$ & $(83.103 .600)$ & $\mathrm{Rp}$ & 974.454 .640 & 0,84168 & $\mathrm{Rp}$ & 820.178 .975 & $\mathrm{Rp}$ & $(6.596 .185 .942)$ \\
\hline 3 & & & $\mathrm{Rp}$ & 1.057 .558 .240 & $\mathrm{Rp}$ & $(83.103 .600)$ & $\mathrm{Rp}$ & 974.454 .640 & 0,77218 & $\mathrm{Rp}$ & 752.457 .775 & $\mathrm{Rp}$ & $(5.843 .728 .167)$ \\
\hline 4 & & & $\mathrm{Rp}$ & 1.057 .558 .240 & $\mathrm{Rp}$ & $(83.103 .600)$ & $\mathrm{Rp}$ & 974.454 .640 & 0,70843 & $\mathrm{Rp}$ & 690.328 .234 & $\mathrm{Rp}$ & $(5.153 .399 .933)$ \\
\hline$\frac{7}{5}$ & & & $\mathrm{Rp}$ & 1.057 .558 .240 & $\mathrm{Rp}$ & $(83.103 .600)$ & $\mathrm{Rp}$ & 974.454 .640 & 0,64993 & $\mathrm{Rp}$ & 633.328 .655 & $\mathrm{Rp}$ & $\begin{array}{l}(4.520 .071 .278) \\
\end{array}$ \\
\hline 6 & & & $\mathrm{Rp}$ & 1.057 .558 .240 & $\mathrm{Rp}$ & $(83.103 .600)$ & $\mathrm{Rp}$ & 974.454 .640 & 0,59627 & $\mathrm{Rp}$ & 581.035 .463 & $\mathrm{Rp}$ & $(3.939 .035 .815)$ \\
\hline$\frac{0}{7}$ & & & $\mathrm{Rp}$ & 1.057 .558 .240 & $\mathrm{Rp}$ & $(83.103 .600)$ & $\mathrm{Rp}$ & 974.454 .640 & 0,54703 & $\mathrm{Rp}$ & 533.060 .058 & $\mathrm{Rp}$ & $(3.405 .975 .757)$ \\
\hline 8 & & & $\mathrm{Rp}$ & 1.057 .558 .240 & $\mathrm{Rp}$ & $(83.103 .600)$ & $\mathrm{Rp}$ & 974.454 .640 & 0,50187 & $\mathrm{Rp}$ & 489.045 .925 & $\mathrm{Rp}$ & $(2.916 .929 .832)$ \\
\hline 9 & & & $\mathrm{Rp}$ & 1.057 .558 .240 & $\mathrm{Rp}$ & $(83.103 .600)$ & $\mathrm{Rp}$ & 974.454 .640 & 0,46043 & $\mathrm{Rp}$ & 448.665 .986 & $\mathrm{Rp}$ & $(2.468 .263 .845)$ \\
\hline 10 & & & $\mathrm{Rp}$ & 1.057 .558 .240 & $\mathrm{Rp}$ & $(83.103 .600)$ & $\mathrm{Rp}$ & 974.454 .640 & 0,42241 & $\mathrm{Rp}$ & 411.620 .171 & $\mathrm{Rp}$ & $(2.056 .643 .675)$ \\
\hline 11 & & & $\mathrm{Rp}$ & 1.057 .558 .240 & $\mathrm{Rp}$ & $(83.103 .600)$ & $\mathrm{Rp}$ & 974.454 .640 & 0,38753 & $\frac{\mathrm{P} p}{\mathrm{Rp}}$ & 377.633 .184 & $\mathrm{Rp}$ & $(1.679 .010 .490)$ \\
\hline 12 & & & $\mathrm{Rp}$ & 1.057 .558 .240 & $\mathrm{Rp}$ & $(83.103 .600)$ & $\mathrm{Rp}$ & 974.454 .640 & 0,35553 & $\mathrm{Rp}$ & 346.452 .463 & $\mathrm{Rp}$ & $(1.332 .558 .028)$ \\
\hline 13 & & & $\mathrm{Rp}$ & 1.057 .558 .240 & $\mathrm{Rp}$ & $(83.103 .600)$ & $\mathrm{Rp}$ & 974.454 .640 & 0,32618 & $\mathrm{Rp}$ & 317.846 .296 & $\mathrm{Rp}$ & $(1.014 .711 .732)$ \\
\hline 14 & & & $\mathrm{Rp}$ & 1.057 .558 .240 & $\mathrm{Rp}$ & $(83.103 .600)$ & $\mathrm{Rp}$ & 974.454 .640 & 0,29925 & $\mathrm{Rp}$ & 291.602 .106 & $\mathrm{Rp}$ & $(723.109 .626)$ \\
\hline 15 & & & $\mathrm{Rp}$ & 1.057 .558 .240 & $\mathrm{Rp}$ & $(83.103 .600)$ & $\mathrm{Rp}$ & 974.454 .640 & 0,27454 & $\mathrm{Rp}$ & 267.524 .868 & $\mathrm{Rp}$ & $(455.584 .757)$ \\
\hline 16 & & & $\mathrm{Rp}$ & 1.057 .558 .240 & $\mathrm{Rp}$ & $(83.103 .600)$ & $\mathrm{Rp}$ & 974.454 .640 & 0,25187 & $\mathrm{Rp}$ & 245.435 .659 & $\mathrm{Rp}$ & $(210.149 .098)$ \\
\hline 17 & & & $\mathrm{Rp}$ & 1.057 .558 .240 & $\mathrm{Rp}$ & $(83.103 .600)$ & $\mathrm{Rp}$ & 974.454 .640 & 0,23107 & $\frac{\mathrm{P}}{\mathrm{Rp}}$ & 225.170 .329 & $\mathrm{Rp}$ & 15.021 .231 \\
\hline 18 & & & $\mathrm{Rp}$ & 1.057 .558 .240 & $\mathrm{Rp}$ & $(83.103 .600)$ & $\mathrm{Rp}$ & 974.454 .640 & 0,21199 & $\mathrm{Rp}$ & 206.578 .284 & $\mathrm{Rp}$ & 221.599 .515 \\
\hline 19 & & & $\mathrm{Rp}$ & 1.057 .558 .240 & $\mathrm{Rp}$ & $(83.103 .600)$ & $\mathrm{Rp}$ & 974.454 .640 & 0,19449 & $\mathrm{Rp}$ & 189.521 .361 & $\mathrm{Rp}$ & 411.120 .876 \\
\hline 20 & & & $\mathrm{Rp}$ & 1.057 .558 .240 & $\mathrm{Rp}$ & $(83.103 .600)$ & $\mathrm{Rp}$ & 974.454 .640 & 0,17843 & $\mathrm{Rp}$ & 173.872 .808 & $\mathrm{Rp}$ & 584.993 .684 \\
\hline 21 & & & $\mathrm{Rp}$ & 1.057 .558 .240 & $\mathrm{Rp}$ & $(83.103 .600)$ & $\mathrm{Rp}$ & 974.454 .640 & 0,16370 & $\mathrm{Rp}$ & 159.516 .338 & $\mathrm{Rp}$ & 744.510 .022 \\
\hline 22 & & & $\mathrm{Rp}$ & 1.057 .558 .240 & $\mathrm{Rp}$ & $(83.103 .600)$ & $\mathrm{Rp}$ & 974.454 .640 & 0,15018 & $\frac{p}{R p}$ & 146.345 .264 & $\mathrm{Rp}$ & 890.855 .287 \\
\hline 23 & & & $\mathrm{Rp}$ & 1.057 .558 .240 & $\mathrm{Rp}$ & $(83.103 .600)$ & $\mathrm{Rp}$ & 974.454 .640 & 0,13778 & $\mathrm{Rp}$ & 134.261 .710 & $\mathrm{Rp}$ & 1.025 .116 .997 \\
\hline 24 & & & $\mathrm{Rp}$ & 1.057 .558 .240 & $\mathrm{Rp}$ & $(83.103 .600)$ & $\mathrm{Rp}$ & 974.454 .640 & 0,12640 & $\mathrm{Rp}$ & 123.175 .881 & $\mathrm{Rp}$ & 1.148 .292 .878 \\
\hline \multirow[t]{2}{*}{25} & & & $\mathrm{Rp}$ & 1.057 .558 .240 & $\mathrm{Rp}$ & $(83.103 .600)$ & Rp & 974.454 .640 & 0,11597 & $\mathrm{Rp}$ & 113.005 .395 & Rp & 1.261 .298 .274 \\
\hline & & & & & & & & & & $\mathrm{Rp}$ & 9.571 .658 .274 & & \\
\hline
\end{tabular}

\subsection{Analisis Kelayakan Investasi}

Analisis kelayakan investasi PLTS studi kasus gedung kuliah POLINKA ditentukan berdasarkan NPV, PI, DPP, dan ROR

Perhitungan ditentukan oleh besar alur kas bersih (Net Cash Flow), faktor diskonto (Discount Factor) dan nilai sekarang alur kas bersih (Present Value Net Cash Flow).

Tabel 9. Hasil Perhitungan Analisis Kelayakan Investasi

\begin{tabular}{ccccl}
\hline \multirow{2}{*}{ No } & \multirow{2}{*}{ Analisis } & \multicolumn{2}{c}{ Hasil Perhitungan } & \multirow{2}{*}{ Keterangan } \\
\cline { 2 - 4 } & dengan $\mathbf{A C}$ & tanpa AC & Letering \\
\hline 1. & NPV & Rp.3.780.859.337 & Rp.1.261.298.274 & Lebih besar dari 1 \\
\hline 2. & PI & 1,1518 & 1,1518 & Lebih besar dari 1 \\
\hline 3. & DPP & 16 tahun 11 bulan 6 hari & 16 tahun 11 bulan 6 hari & $\begin{array}{l}\text { Kurang dari umur sistem } \\
\text { yang direncanakan }\end{array}$ \\
\hline 4. & IRR & $10,84 \%$ & $10,84 \%$ & $\begin{array}{l}\text { Lebih besar dari suku bunga } \\
\text { yang digunakan }\end{array}$ \\
\hline
\end{tabular}

\section{Kesimpulan}

1. Hasil perhitungan analisis kelayakan investasi perencanan pembangunan PLTS pada gedung kuliah POLINKA dengan beban rencana menggunakan AC sebesar 56.763 watt dengan total beban $476.809 \mathrm{Wh}$ selama 8 jam dinyatakan bahwa investasi PLTS ini layak. Dengan jumlah komponen PLTS yang dibutuhkan yaitu inverter 15 buah, SCC 210 buah, batere 5040 buah, modul PV 2520 buah, menghasilkan daya 589.680 watt. Biaya investasi yang dibutuhkan sebesar Rp. 24.911.080.000, biaya pemeliharaan dan operasional sebesar Rp. 249.110.800, dan biaya energi Rp. 2.616,13/kWh.

2. Hasil perhitungan analisis kelayakan investasi perencanan pembangunan PLTS pada gedung kuliah POLINKA dengan beban rencana tanpa menggunakan AC sebesar 18.963 watt dengan total beban $159.289 \mathrm{Wh}$ selama 8 jam dinyatakan bahwa investasi PLTS ini layak. Dengan jumlah komponen PLTS yang dibutuhkan yaitu inverter 5 buah, SCC 70 buah, batere 1680 buah, modul PV 840 buah menghasilkan daya 196.560 watt. Biaya investasi yang dibutuhkan sebesar Rp. 8.310.360.000, biaya pemeliharaan dan operasional sebesar Rp. 83.103.600, dan biaya energi Rp. 2.618,23/kWh.

3. Jika dilihat hanya dari sisi ekonominya, energi baru terbarukan salah satunya PLTS biayanya masih tinggi dan tidak layak direalisasikan dibandingkan energi berbahan bakar fosil.

4. Jika dalam pengambilan keputusan ditambahan dari luar sisi ekonominya, seperti dari pengaruh lingkungan, pengaruh cadangan sumber daya alam dan dari segi manfaat jika subsidi dari pemerintah ke PT. PLN menjadi ke lembaga pendidikan yang membangun PLTS karena kelebihan biaya energi sistem PLTS maka perencanaan PLTS layak direalisasikan.

\section{Referensi}

[1] Hanna J.P. 2012. Analisis Keekonomian Kompleks Perumahan Berbasis Energi Sel Surya (Studi Kasus : Perumahan Cyber Orchid Town Houses, Depok). Skripsi FT UI.

[ 2 ] http://www.rumusstatistik.com/2013/07/rata-rata-meanatau-rataan.html

[ 3 ] Balalembang, J. 2013. Scribd [Online]. Perencanaan Pembangkit Listrik Tenaga Surya (PLTS) terpusat Pada Kampung Puay Distrik Sentani Timur. tersedia: https://www.scribd.com/doc/ 136195115/Bab-1-5Juianto\#scribd

[ 4 ] Jati, I.N. 2011. Studi Pemanfaatan PLTS Hibrid dengan PLN di Vila Adleson Ubud. Denpasar. Tesis Universitas Udayan.

[5] Liem Ek Bien, Ishak Kasim \& Wahyu Wibowo, Perancangan Sistem Hibrid Pembangkit Listrik Tenaga Surya dengan Jala-jalanListrik PLN untuk Rumah Perkotaan, Jetri, Volume 8, Nomor 1, Agustus 2008, Halaman 37-56, ISSN 1412-0372 
[6] Alwi Abubakar. 2013. Ekonomi Teknik. Bahan Ajar Magister Elektro Universitas Tanjungpura: ppt

[ 7 ] Badan Meteorologi, Klimstologi dan Giofisika (BMKG), data lama penyinaran matahari, Ketapanga (KALBAR), 2015.

\section{Biography}

Yudi Chandra, lahir di Ketapang (KAL-BAR), pada tanggal 23 September 1986, putra kedua dari empat bersaudara, pasangan Masyrum dan Suriyati. telah menempuh pendidikan formal, antara lain di SD Negeri 07 Ketapang (Tahun 19921998), SLTP Negeri 1 Ketapang (Tahun 1998-2001), dan SMK Negeri 2 Ketapang (Tahun 2001-2004). Setelah lulus dari SMK tahun 2004, Penulis melanjutkan pendidikan di Politeknik Negeri Pontianak (POLNEP) mengambil program Diploma Tiga (D-III) Jurusan Teknik Mesin (Tahun 20042007), kemudian melanjutkan ke program Diploma Empat (DIV) Politeknik Negeri Bandung (POLBAN) Jurusan Teknik Mesin, Program Studi Teknik Mesin Produksi dan Perawatan (Tahun 2007-2009). Pada akhir tahun 2012 Penulis melanjutkan pendidikan ke jenjang S2 di Program Magister Teknik Elektro Fakultas Teknik Universitas Tanjungpura. 